\title{
ANALISIS FAKTOR YANG MEMPENGARUHI KESUKSESAN USAHA PADA PEDAGANG HANDPHONE SEPANJANG JALAN MOSES YOGYAKARTA
}

\author{
Yati Suhartini, Ayu Hadiati \\ Universitas PGRI Yogyakarta \\ Jl.PGRI I No.117 Sonosewu, Yogyakarta. \\ e-mail:yati.suhartini@yahoo.com
}

\begin{abstract}
The research was carried out to find the influence of five business location factors such as rent expense, infrastructure, business environment, consumer, and security on the success of the mobile phone business a long Jalan Moses, Yogyakarta. The respondents of the research were all of the handphone traders a long Jalan Moses, as many as 81 respondents. The data was derived from a survey and collected by applying questionnaires, and analyzed by using multiple linear regressions. This research indicated that factors of rent expense, infrastructure, business environment, consumer, and security, all together showed a significant influence on the business success. These were indicated by the value of $F$ amounting to 24,132 with the significance level of 0,000, where as $R$ square counting to 0,591. The regression coefficient of each factor of rent expense, infrastructure, business environment, consumer, and security toward business success are 0,368 $\left(X_{1}\right) ; 0,294\left(X_{2}\right) ; 0,399\left(X_{3}\right) ; 0,311\left(X_{4}\right) ; 0,394\left(X_{5}\right)$; and the significant level of each factor are 0,003; 0,031,0,007, 0,031, and 0,020 respectively.
\end{abstract}

Keywords: Rent Expense, Infrastructure, Business Environment, Consumer, and Security Toward Business Success.

\section{Pendahuluan}

Salah satu faktor yang harus diperhatikan oleh pengusaha demi keberhasilan usahanya adalah lokasi usaha. Lokasi usaha merupakan kunci yang efisiensi dan efektifitas bagi keberlangsungan perusahaan jangka panjang (Haming, 2011). Agar usaha yang dijalankan bisa bersaing secara efektif, maka penentuan tempat yang strategis akan sangat membantu kelancaran usaha. Karena semakin dekat jarak dari penjual, maka konsumen akan semakin mudah untuk menjangkau dan makin jauh dari tempat penjual, konsumen makin enggan membeli karena biaya transportasi untuk mendatangi tempat penjual semakin mahal. Memilih lokasi usaha juga berarti meminimalkan faktor-faktor negatif dan memaksimalkan potensi yang dimiliki.

Pada dasarnya, keputusan lokasi sering bergantung kepada tipe bisnis. Untuk keputusan lokasi industri, strategi yang diguna- kan biasanya adalah strategi untuk meminimalkan biaya. Hal ini disebabkan perusahaan manufaktur mendapati biaya cenderung sangat berbeda di antara lokasi-lokasi yang berbeda. Berbeda halnya untuk bisnis eceran dan jasa profesional, strategi yang digunakan terfokus pada memaksimalkan pendapatan. Walaupun demikian, strategi lokasi pemilihan gudang, dapat ditentukan oleh kombinasi antara biaya dan kecepatan pengiriman. Secara umum, tujuan strategi lokasi adalah untuk memaksimalkan keuntungan lokasi bagi perusahaan (Heizer \& Render 2009).

Penelitian mengenai lokasi tidak hanya dibutuhkan oleh perusahaan skala besar, namun perusahaan kecil dan menengahpun juga wajib untuk memilih lokasi usaha yang baik agar usaha bisa bertahan dan terus berjalan. Pemilihan lokasi akan berdampak pada keberlangsungan usaha juga keuntungan yang akan didapat. Lokasi menjadi salah 
satu faktor keunggulan bersaing dari perusahaan sehingga lokasi dimaksud memiliki nilai strategis dan menjadi bagian dari kebijakan jangka panjang perusahaan (Haming, 2011). Seperti usaha penjualan handphone, lokasi usaha yang strategis ditambah nilai plus yang ditawarkan tentu akan meningkatkan kesuksesan usahanya.

Menurut survei yang dilakukan oleh $\mathrm{Pu}$ sat Kajian Komunikasi (Puskakom) UI tahun 2015, jumlah pengguna internet di Indonesia sudah mencapai angka 88,1 juta. Karena pangsa pasar yang potensial itulah, menarik minat para pengusaha untuk mendirikan usaha penjualan handphone.

Di Yogyakarta, perkembangan bisnis retail handphone terus berlangsung, dan sentra-sentra perdagangan handphone terus bermunculan seiiring dengan pembukaan beberapa mall baru. Seperti yang terlihat di sepanjang jalan Moses, terdapat puluhan gerai handphone kecil yang berjualan handphone baru maupun bekas sambil berjualan barang komplementernya. Meskipun terlihat tidak ada strategi pemasaran yang diterapkan tetapi mereka melihat masih ada "kue" yang tersisa yang bisa dijadikan ladang bisnis dalam bisnis handphone ini. (Aro: 2008, online).

Latar belakang tersebut di atas menjadi dasar dari dilakukannya penelitian ini dengan judul "Analisis Faktor yang Mempengaruhi Kesuksesan Usaha pada Pedagang Handphone Sepanjang Jalan Moses Yogyakarta."

\section{Perumusan Masalah}

Berdasarkan uraian yang telah dikemukakan di atas maka dapat dirumuskan permasalahan penelitian sebagai berikut:

1. Bagaimana pengaruh biaya sewa lokasi terhadap kesuksesan usaha penjualan handphone di sepanjang jalan Moses?

2. Bagaimana pengaruh kedekatan infrastruktur terhadap kesuksesan usaha penjualan handphone di sepanjang jalan Moses?

3. Bagaimana pengaruh lingkungan bisnis terhadap kesuksesan usaha penjualan handphone di sepanjang jalan Moses?
4. Bagaimana pengaruh kedekatan konsumen terhadap kesuksesan usaha penjualan handphone di sepanjang jalan Moses?

5. Bagaimana pengaruh keamanan terhadap kesuksesan usaha penjualan handphone di sepanjang jalan Moses?

6. Bagaimana pengaruh biaya sewa lokasi, kedekatan infrastruktur, lingkungan bisnis, kedekatan konsumen dan keamanan secara simultan terhadap kesuksesan usaha penjualan handphone di sepanjang jalan Moses?

\section{Tujuan Penelitian}

Berdasarkan permasalahan di atas, maka tujuan penelitian secara umum adalah untuk menguji pengaruh faktor-faktor biaya sewa, kedekatan infrastruktur, lingkungan bisnis, kedekatan konsumen, dan keamanan terhadap kesuksesan usaha pada pedagang handphone sepanjang jalan Moses, Yogyakarta.

\section{Kajian Teori}

\section{Pemilihan Lokasi Usaha}

Salah satu faktor yang menentukan apakah suatu lokasi menarik untuk dikunjungi atau tidak adalah tingkat aksesibilitas. Tingkat aksesibilitas adalah tingkat kemudahan untuk mencapai suatu lokasi ditinjau dari lokasi lain di sekitarnya. Tingkat aksesibilitas dipengaruhi oleh jarak, kondisi prasarana perhubungan seperti kondisi jalan dan lebar jalan, ketersediaan berbagai sarana penghubung termasuk frekuensi dan tingkat keamanan serta kenyamanan untuk melalui jalur tersebut (Tarigan, 2006).

\section{Strategi Pemilihan Lokasi Usaha}

Menurut Fandy Tjiptono (2012), pemilihan lokasi usaha memerlukan pertimbangan cermat terhadap faktor-faktor berikut:

a. Lokasi yang mudah dilalui dan mudah dijangkau sarana transportasi.

b. Visibilitas, yaitu lokasi atau tempat yang dapat dilihat dengan jelas dari jarak 
pandang normal.

c. Lalu Lintas.

d. Tempat parkir yang luas, nyaman dan aman baik untuk kendaraan roda dua maupun roda empat.

e. Ekspansi, yaitu tersedia tempat untuk perluasan usaha.

f. Lingkungan yaitu daerah sekitar yang mendukung jasa yang ditawarkan.

g. Kompetisi yaitu lokasi pesaing, dalam menentukan lokasi perlu dipertimbangkan apakah di jalan atau di daerah yang sama terdapat usaha yang sama.

h. Peraturan pemerintah.

\section{Kesuksesan Usaha}

Kesuksesan usaha adalah sebuah hasil yang dicapai dari kemampuan untuk mengembangkan ide-ide baru dan menemukan cara-cara baru dalam melihat masalah dan peluang, serta kemampuan untuk menerapkan solusi kreatif terhadap masalah dan peluang untuk meningkatkan atau untuk memperkaya kehidupan orang-orang. Kesuksesan diidentikan dengan perkembangan usaha meliputi meningkatnya jumlah pelanggan, bertambahnya omset, bertambahnya laba, pencapaian BEP, nama perusahaan semakin dikenal dan bertambahnya jumlah karyawan (Zimmerer 2008).

\section{Biaya Sewa}

Biaya sewa adalah kewajiban perusahaan yang harus dibayarkan kepada pihak lain atas jasa pihak lain, yang telah meminjamkan sesuatu (aktiva) untuk kepentingan perusahaan. Perusahaan kadangkala membayarkan biaya sewa untuk periode lebih dari satu tahun, maka atas biaya sewa tersebut harus diamortisasi/diakui sebagai biaya sewa sesuai masa manfaat biaya sewa tersebut (Wibowo: 2014 , online).

Apabila lokasi usaha sangat strategis dan memiliki prospek yang baik, faktor tingginya biaya sewa tidak terlalu dipedulikan oleh si penyewa selama biaya tersebut masih dirasa pantas dan sesuai dengan letak, infrastruktur yang memadai dan faktor-faktor la- in. Mempertimbangkan harga sewa dengan nilai tambah yang dimiliki suatu tempat usaha, akan membuat pengusaha atau penyewa lokasi usaha menjadi lebih teliti dalam memutuskan.

\section{Kedekatan Infrastruktur}

Infrastruktur adalah sistem fisik yang menyediakan sarana transportasi, drainase, pengairan, bangunan gedung serta fasilitas publik lainnya, yang dibutuhkan untuk memenuhi berbagai kebutuhan dasar manusia baik itu kebutuhan ekonomi maupun kebutuhan sosial (Grigg, 1988). Menurut Kodoatie (2005), infrustruktur yaitu sistem yang menopang sistem sosial dan sistem ekonomi yang sekaligus menjadi penghubung dengan sistem lingkungan, dimana sistem ini dapat dipakai sebagai dasar di dalam mengambil kebijakan. Dalam pemilihan lokasi usaha, faktor kedekatan infrastruktur sangat penting bagi kelancaran usahanya. Infrastruktur akan menjadi insentif dalam pemilihan lokasi (Haming, 2011).

\section{Lingkungan Bisnis}

Lingkungan bisnis adalah keseluruhan hal-hal mengenai keadaan eksternal yang berpengaruh terhadap perusahaan. Lingkungan bisnis terdiri dari dua jenis, yaitu (Basri, 2005):

a. Lingkungan bisnis yang berpengaruh langsung (Direct Action Elements), terdiri dari: konsumen, supplier, pesaing, labor union, media, institusi keuangan, grup pemerhati khusus dan pemerintah.

b. Lingkungan bisnis yang berpengaruh tidak langsung (In-direct Action Elements), terdiri atas: lingkungan ekonomi, politik, sosial budaya, teknologi, alam, hukum, etika, dan internasional.

\section{Kedekatan Konsumen/Pasar}

Kedekatan dengan pasar memungkinkan sebuah perusahaan memberikan pelayanan yang lebih baik kepada pelanggan, dan sering menghemat biaya pengiriman. 
Selain itu, dengan produksi yang just in ti$m e$, pemasok menginginkan lokasi yang dekat dengan pelanggan (Heizer \& Render, 2009).

Dari penjelasan tersebut, maka yang dimaksud kedekatan dengan konsumen adalah persepsi pedagang mengenai kedekatan dengan pemukiman penduduk, kedekatan dengan lalu lintas dan pejalan kaki.

\section{Keamanan}

Keamanan berarti keadaan bebas dari bahaya atau gangguan, atau dapat juga berarti terlindungi (Kamus Besar Bahasa Indonesia, online). Lokasi usaha yang berada di keramaian kota dapat meningkatkan keamanan usaha. Para pemilik usaha tentunya lebih memilih lokasi usaha yang berada di keramaian agar usahanya lebih terjaga, begitu pula usaha handphone mengingat harga barang-barang tersebut relatif mahal dan termasuk benda berharga. Faktor keamanan menjadi prioritas demi keberlangsungan usaha tanpa adanya gangguan. Keamanan dalam penelitian ini meliputi keamanan dari kriminalitas, keamanan konstruksi atau bangunan dan keamanan bagi kendaraan pengunjung.

\section{Penelitian Terdahulu}

Penelitian-penelitian sebelumnya yang telah mengkaji dan memiliki kaitan dengan variabel penelitian ini, antara lain sebagai berikut:
1. Penelitian oleh Indarti pada tahun 2004 dengan judul "Business Location and Success: The Case of Internet Cafe Business in Indonesia". Penelitian ini menggunakan 5 faktor pemilihan lokasi yang menjadi pertimbangan utama yakni, ketersediaan ISP (Internet Service Provider) yang memadai, kedekatan dengan konsumen, keamanan, ketersediaan infrastruktur yang memadai, dan lingkungan bisnis. Dari hasil analisis regresi, terdapat 3 faktor yang memiliki pengaruh paling besar terhadap kesuksesan bisnis yakni, ketersediaan infrastruktur, kedekatan dengan sekolah/universitas, dan keamanan.

2. Penelitian oleh Ifrina Nurita, dkk., pada tahun 2013 yang berjudul "Identifikasi Pengaruh Lokasi Usaha terhadap Tingkat Keberhasilan Usaha Minimarket Waralaba di Kabupaten Jember dengan Sistem Informasi Geografis". Penelitian ini menerapkan pendekatan Structured Analisys and Design (SSAD) yang berbasis model Rapid Application Development (RAD). Analisis secara spasial menunjukkan bahwa kedekatan lokasi dengan perguruan tinggi serta tingginya kepadatan dan pendapatan per kapita penduduk berpengaruh terhadap tingkat keberhasilan usaha minimarket waralaba di Kabupaten Jember.

\section{Kerangka Konseptual Penelitian}

Berdasarkan kajian teori di atas, kerangka konseptual yang mendasari penelitian ini digambarkan sebagai berikut:

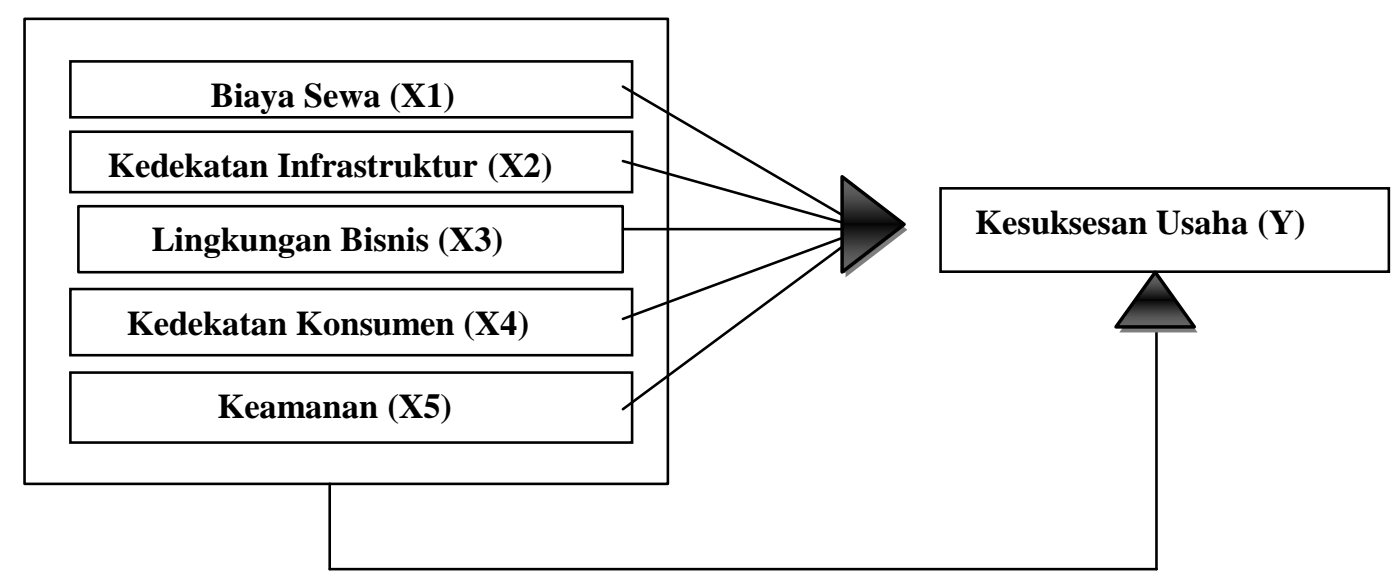

Gambar 1. Kerangka Konseptual Penelitian. 
Kerangka konseptual di atas dapat dijelaskan bahwa biaya sewa $\left(\mathrm{X}_{1}\right)$, kedekatan infrastruktur $\left(\mathrm{X}_{2}\right)$, lingkungan bisnis $\left(\mathrm{X}_{3}\right), \mathrm{Ke}$ dekatan konsumen (X4), dan Keamanan (X 5) mempengaruhi kesuksesan usaha (Y). Seorang pengusaha perlu mempertimbangkan faktor-faktor yang mempengaruhi kesuksesan bisnis mereka agar mempunyai kesuksesan usaha yang baik, sehingga tujuan organisasi bisa dicapai secara efisien dan efektif.

\section{Perumusan Hipotesis}

Dari perumusan masalah, landasan teori dan kerangka konseptual, maka dapat ditarik hipotesis, sebagai berikut:

H1: Diduga biaya sewa berpengaruh positif terhadap kesuksesan usaha penjualan handphone di sepanjang jalan Moses, Yogyakarta.

H2: Diduga kedekatan infrustruktur berpengaruh positif terhadap kesuksesan usaha penjualan handphone di sepanjang jalan Moses, Yogyakarta.

H3: Diduga lingkungan bisnis berpengaruh positif terhadap kesuksesan usaha penjualan handphone di sepanjang jalan Moses, Yogyakarta.

H4: Diduga kedekatan konsumen berpengaruh positif terhadap kesuksesan $\mathrm{u}-$ saha penjualan handphone di sepanjang jalan Moses, Yogyakarta.

H5: Diduga keamanan berpengaruh positif terhadap kesuksesan usaha penjualan handphone di sepanjang jalan Moses, Yogyakarta.

\section{Metode Penelitian}

\section{Populasi dan Sampel Penelitian}

Populasi penelitian ini yaitu seluruh pedagang handphone yang ada di sepanjang jalan Moses yaitu sebanyak 81 kios. Penelitian ini menggunakan sampling jenuh karena jumlah populasi kurang dari 100.

\section{Variabel dan Indikator Penelitian}

Variabel penelitian ini meliputi variabel independen dan variabel dependen.

a. Variabel Independen $(X)$.

Variabel independen (X) terdiri dari biaya sewa $\left(\mathrm{X}_{1}\right)$, kedekatan infrastruktur $\left(\mathrm{X}_{2}\right)$, lingkungan bisnis $\left(\mathrm{X}_{3}\right)$, kedekatan konsumen (X4), dan keamanan (X5).

1) Biaya Sewa $\left(X_{1}\right)$, dalam penelitian ini diukur dengan indikator: a). Harga sewa kios cukup terjangkau dan sesuai dengan fasilitas; b). Kios yang di sewa membutuhkan renovasi atau tidak; c). Pemilik bangunan memberikan insentif bagi penyewa kios atau tidak.

2) Kedekatan Infrastruktur $\left(X_{2}\right)$, dalam penelitian ini diukur dengan indikator: a). Saluran listrik memadai; b). Saluran air lancar; c). Lahan parkir bagi para konsumen tersedia cukup luas baik bagi roda dua maupun roda empat.

3) Lingkungan bisnis $\left(X_{3}\right)$, dalam penelitian ini diukur dengan indikator: a). Dekat dengan bisnis lain membuat lokasi usaha menjadi lebih ramai oleh pengunjung dengan beragam keperluan membeli; b). Berlokasi di kawasan bisnis handphone dengan banyak pesaing dapat menarik konsumen; c). Berada dekat dengan supplier membuat arus barang menjadi lebih cepat dan mudah.

4) Kedekatan Konsumen (X4), dalam penelitian ini diukur dengan indikator: a). Letak lokasi usaha berada di tengah pemukiman penduduk; b). Letak lokasi usaha dikelilingi oleh lalu lintas yang padat; c). Letak lokasi usaha yang berada di dekat kampus selalu dipadati oleh pejalan kaki.

5) Keamanan (X5), dalam penelitian ini diukur dengan indikator: a). Kawasan lokasi di tengah keramaian kota sehingga keamanan terjamin. b). Kios yang ditempati, merupakan bangunan yang kuat. c). Adanya tukang parkir menjamin keamanan bagi kendaraan konsumen.

\section{b. Variabel Dependen (Y).}


Variabel Dependen (Y) yaitu kesuksesan usaha yang diukur dengan indikator:

1) Konter handphone mengalami peningkatan jumlah pelanggan.

2) Konter handphone mengalami peningkatan omset.

3) Konter handphone mengalami peningkatan laba.

\section{Instrumen Penelitian, Cara Pengukuran, dan Teknik Pengumpulan Data}

Penyusunan instrumen penelitian yang berupa butir-butir soal (kuesioner) didasarkan atas kisi-kisi kuesioner yang telah dikontruksi sesuai landasan teori yang telah dikaji dan berpedoman pada indikator dari variabel-variabel penelitian yang dijabarkan dalam beberapa butir soal. Semua butir soal dalam kuesioner berupa pertanyaan obyektif sehingga responden hanya memberi tanda silang (X) pada salah satu jawaban yang dianggap paling sesuai dengan keadaannya. Setelah kuesioner disusun, butir-butir kuesioner tersebut diuji cobakan kepada sejumlah responden untuk mengetahui validitas dan reliabilitas instrumen.

Untuk mengukur jawaban responden dipergunakan skala bertingkat model Likert dengan 5 altematif jawaban. Agar data yang diperoleh berwujud data kuantitatif, maka setiap butir soal diberi skor sesuai jawabannya, yaitu jawaban: Sangat Tidak Setuju $=1$, Tidak Setuju $=2$, Kurang Setuju $=3$, Setuju $=4$, Sangat Setuju $=5$ ( Sugiyono, 2014).

Teknik pengumpulan data dalam penelitian ini yaitu dengan penyebaran kuesioner kepada responden. Pada langkah pertama, kuesioner diberikan secara random kepada 30 orang responden yang terpilih untuk pengujian awal terhadap isi kuesioner. Kuesioner yang lolos pada pegujian awal tersebut kemudian disebarkan kepada sisa responden dalam populasi yang berbeda dari responden pada langkah pertama.

\section{Teknik Analisis Data}

\section{Analisis Regresi Linier Berganda}

Analisis regresi linier berganda adalah hubungan secara linear antara dua atau lebih variabel bebas $\left(\mathrm{X}_{1}, \mathrm{X}_{2}, \ldots \mathrm{X}_{\mathrm{n}}\right)$ dengan variabel terikat $(\mathrm{Y})$. Analisis ini untuk mengetahui apakah masing-masing variabel bebas berhubungan positif atau negatif dan untuk memprediksi nilai dari variabel terikat apabila nilai variabel independen mengalami kenaikan atau penurunan (Duwi Consultan: 2011, online).

Persamaan regresi linear berganda sebagai berikut:

$$
\mathbf{Y}=\mathbf{a}+\mathbf{b}_{1} \mathbf{X}_{1}+\mathbf{b}_{2} \mathbf{X}_{2}+\mathbf{b}_{3} \mathbf{X}_{3}+\ldots+\mathbf{b}_{\mathbf{n}} \mathbf{X}_{\mathbf{n}}
$$

Keterangan:

Y : Variabel terikat (dependent).

$\mathbf{X}(\mathbf{1}, \mathbf{2 , 3}, \ldots)$ : Variabel bebas (independent).

a : Konstanta dari rata-rata nilai. Y pada saat $\mathrm{X}(1,2,3 .$.$) sama$ dengan nol.

b $(\mathbf{1}, \mathbf{2}, \mathbf{3}, \ldots)$ : Nilai koefisien regresi.

\section{Uji Hipotesis}

\section{Uji t}

Uji t digunakan untuk mengetahui pengaruh dari masing-masing variabel bebas terhadap variabel terikat. Dasar pengambilan keputusan Uji t parsial dengan output SPSS (SPSS Indonesia, online), sebagai berikut:

a) Berdasarkan nilai t hitung dan t tabel:

1. Jika nilai $t$ hitung $>t$ tabel maka variabel bebas berpengaruh terhadap variabel terikat.

2. Jika nilai thitung $<\mathrm{t}$ tabel maka variabel bebas tidak berpengaruh terhadap variabel terikat.

b) Berdasarkan nilai signifikan hasil output SPSS:

1. Jika nilai Sig. < 0,05 maka variabel bebas berpengaruh signifikan terhadap variabel terikat.

2. Jika nilai Sig. > 0,05 maka variabel bebas tidak berpengaruh signifikan terhadap variabel terikat.

3. Tingkat kepercayaan yang digunakan adalah $95 \%$, maka nilai $\alpha=0,05$. 


\section{Uji F}

Uji $F$ bertujuan untuk mengetahui apakah variabel bebas secara bersama-sama atau simultan berpengaruh terhadap variabel terikat. Dasar pengambilan keputusan Uji F dengan output SPSS (SPSS Indonesia online) sebagai berikut:

a) Jika nilai Sig. < 0,05 maka variabel bebas secara simultan berpengaruh signifikan terhadap variabel terikat.

b) Jika nilai Sig. > 0,05 maka variabel bebas secara simultan tidak berpengaruh signifikan terhadap variabel terikat.

c) Tingkat kepercayaan yang digunakan adalah $95 \%$, maka nilai $\alpha=0,05$.

\section{Koefisiensi Determinasi ( $\mathbf{R}^{2}$ )}

Besarnya koefisien determinasi $\left(\mathrm{R}^{2}\right)$ menunjukkan persentase pengaruh variabel bebas terhadap variabel terikat. Apabila $\mathrm{R}^{2}$
$=0$, maka model regresi yang digunakan tidak menjelaskan sedikitpun variasi dari nilai $\mathrm{Y}$. Apabila $\mathrm{R}^{2}=1$, maka model yang digunakan menjelaskan $100 \%$ variasi dari nilai $\mathrm{Y}$ atau terjadi kecocokan sempurna. Ketidaktepatan titik-titik berada pada garis regresi disebabkan adanya faktor-faktor lain yang berpengaruh terhadap variabel bebas. Bila tidak ada penyimpangan tentunya tidak akan ada error, Darmawan (2013).

\section{Hasil Penelitian}

\section{Karakteristik Responden}

Penelitian ini menggunakan 81 responden yaitu seluruh pedagang handphone yang ada di sepanjang jalan Moses, yang karakteristiknya disajikan melalui tabel di bawah ini.

Tabel 1. Jenis Kelamin Responden.

\begin{tabular}{lcc}
\hline \multicolumn{1}{c}{ Jenis Kelamin } & Frekuensi & Persentase (\%) \\
\hline Laki-laki & 56 & 69,1 \\
Perempuan & 25 & 30,9 \\
\hline Total & $\mathbf{6 0}$ & $\mathbf{1 0 0}$ \\
\hline
\end{tabular}

Sumber: Data primer diolah, 2016.

Tabel 1 di atas menunjukkan bahwa responden berjenis kelamin laki-laki sebanyak $69,1 \%$ dan responden perempuan sebanyak
$30,9 \%$. Secara umum perbandingan pedagang laki-laki dengan perempuan sebesar 2 dibanding 1 .

Tabel 2. Usia Responden.

\begin{tabular}{|c|c|c|}
\hline Usia/Tahun & Frekuensi & Persentase (\%) \\
\hline $17-25$ & 23 & 28,4 \\
\hline $26-35$ & 40 & 49,4 \\
\hline $36-45$ & 16 & 19,8 \\
\hline$>45$ & 2 & 2,5 \\
\hline Total & 81 & 100 \\
\hline
\end{tabular}

Sumber: Data primer diolah, 2016. 
Tabel 2 di atas menunjukan bahwa usia responden yang terbanyak pada usia 26 - 35 tahun sebanyak 40 orang $(49,4 \%)$. Selanjutnya yang kedua dengan usia 17 - 25 tahun sebanyak 23 orang $(28,4 \%)$, ketiga dengan umur 36 - 45 tahun sebanyak 16 orang (19, $8 \%$ ), dan yang terakhir responden dengan umur $>45$ tahun sebanyak 2 orang $(2,5 \%)$.

Tabel 3. Pendidikan Responden.

\begin{tabular}{|c|c|c|}
\hline Pendidikan & Frekuensi & Persentase (\%) \\
\hline SMU & 38 & 46,9 \\
\hline Diploma & 14 & 17,3 \\
\hline$S_{1}$ & 28 & 34,6 \\
\hline Magister & 1 & 1,2 \\
\hline Jumlah & 81 & 100 \\
\hline
\end{tabular}

Sumber: Data primer diolah, 2016.

Tabel 3 di atas menunjukan bahwa pendidikan responden terbesar adalah SMU sebanyak 38 orang $(46,9 \%)$, selanjutnya responden berpendidikan S1 sebanyak 28 orang $(34,6 \%)$, kemudian yang urutan ketiga res- ponden berpendidikan Diploma sebanyak 14 orang $(17,3 \%)$, dan yang terakhir responden berpendidikan Magister sebanyak 1 orang $(1,2 \%)$.

Tabel 4. Lama Usaha Responden.

\begin{tabular}{lcc}
\hline \multicolumn{1}{c}{ Lama Usaha } & Frekuensi & Persentase (\%) \\
\hline$<1$ tahun & 14 & 17,3 \\
$1-5$ tahun & 40 & 49,4 \\
$6-10$ tahun & 25 & 30,9 \\
$>10$ tahun & 2 & 2,5 \\
\hline Jumlah & $\mathbf{8 1}$ & $\mathbf{1 0 0}$ \\
\hline
\end{tabular}

Sumber: Data primer diolah, 2016.

Tabel 4 di atas menunjukkan bahwa responden yang terbesar dengan lama usaha 1 5 tahun sebanyak 40 orang $(49,4 \%)$. Selanjutnya yang kedua dengan lama usaha 6 - 10 tahun sebanyak 25 orang $(30,9 \%)$, yang ketiga lama $<1$ tahun sebanyak 14 orang $(17,3$ $\%$ ), keempat lama usaha $>10$ tahun sebanyak 2 orang $(2,5 \%)$.

Tabel 5. Jumlah Karyawan Responden.

\begin{tabular}{lcc}
\hline \multicolumn{1}{c}{ Jumlah Karyawan } & Frekuensi & Persentase (\%) \\
\hline Tidak ada & 15 & 18,5 \\
1 - 5 orang & 61 & 75,3 \\
$>5$ orang & 5 & 6,2 \\
\hline Jumlah & $\mathbf{8 1}$ & $\mathbf{1 0 0}$ \\
\hline
\end{tabular}

Sumber: Data primer diolah, 2016. 
Tabel 5 di atas menunjukan bahwa 61 responden $(75,3 \%)$ memiliki jumlah karyawan 1 - 5 orang selanjutnya responden dengan tanpa karyawan sebesar 15 responden dan jumlah karyawan $>5$ orang sebanyak 5 responden $(6,2 \%)$.

\section{Hasil Uji Validitas dan Reliabilitas}

Uji validitas menggunakan koefisien korelasi Product Momen Pearson dengan alat bantu SPSS 16. Butir kuisioner dinyatakan valid jika nilai $r$ yang dihasilkan adalah positif dan lebih besar dari $\mathrm{r}$ alpha $(0,05)$. Dari pengolahan data diperoleh hasil bahwa koefisien korelasi berada pada kisaran 0,471 - 0,919 dan nilai $\mathrm{r}$ alpha yang dimiliki tiap butirnya lebih besar dari 0,05. Ini berarti, semua butir kuesioner dapat dikatakan valid.

Uji reliabilitas dengan menggunakan koefisien Cronbach Alpha dengan alat bantu SPSS 20. Suatu angket dikatakan reliabel jika nilai $r$ yang dihasilkan adalah positif dan lebih besar dari $\mathrm{r}$ alpha $(0,05)$. Dari pengolahan data diperoleh hasil bahwa koefisien korelasi berada pada kisaran 0,678 0,806 dan nilai $\mathrm{r}$ alpha yang dimiliki tiap butirnya lebih besar dari 0,05. Ini berarti, semua butir kuesioner dapat dikatakan reliabel.

\section{Analisis Regresi Berganda}

Berikut ini tabel hasil analisis Regresi Linier Berganda dari output SPSS.

Tabel 6. Hasil Pengujian Regresi Linear Berganda.

\begin{tabular}{llllll}
\hline \multicolumn{1}{c}{ Variabel } & $\begin{array}{c}\text { Koefisien } \\
\text { Regresi }\end{array}$ & St. Error & t hitung & Sig. & Kesimpulan \\
\hline Biaya sewa & 0,368 & 0,118 & 3,117 & 0,003 & Signifikan \\
Kedekatan infrastruktur & 0,294 & 0,134 & 2,198 & 0,031 & signifikan \\
Lingkungan bisnis & 0,399 & 0,144 & 2,769 & 0,007 & Signifikan \\
Kedekatan konsumen & 0,311 & 0,142 & 2,196 & 0,031 & Signifikan \\
Keamanan & 0,394 & 0,166 & 2,372 & 0,020 & Signifikan \\
\hline
\end{tabular}

Konstanta $=-0,222$

$R=0,785, R^{2}=0,713, F=24,132$, Sig. $F=0,000, N=81$

Sumber: Data Primer diolah, 2016.

Dari hasil analisis regresi dapat dibuat persamaan regresi berganda sebagai berikut:

$$
Y=-0,222+0,368 X_{1}+0,294 X_{2}+0,399 X_{3}+0,311 X_{4}+0,394 X_{5}
$$

Dari regresi di atas dapat diketahui, nilai koefisiensi regresi dari nilai a untuk konstanta $=-0,222$ dan koefisiensi biaya sewa $\left(\mathrm{X}_{1}\right)=0,368$, dengan signifikansi 0,003, kedekatan infrastruktur $\left(\mathrm{X}_{2}\right)=0,294$ dengan signifikansi 0,031, lingkungan bisnis $\left(\mathrm{X}_{3}\right)=$ 0,399 dengan signifikansi 0,007, kedekatan konsumen $\left(\mathrm{X}_{4}\right)=0,311$ dengan signifikansi
0,031, dan keamanan $\left(X_{5}\right)=0,394$ dengan signifikansi 0,020 . Persamaan di atas menunjukkan adanya pengaruh signifikan positif dari variabel-variabel bebas $\mathrm{X}$ (biaya sewa, kedekatan infrastruktur, lingkungan bisnis, kedekatan konsumen, dan keamanan) terhadap variabel terikat Y (kesuksesan usaha). 
Analisis Koefisiensi Determinasi ( $\left.\mathbf{R}^{2}\right)$

Berikut ini tabel Uji Koefisien Determinasi dari output SPSS:

Tabel 7. Hasil Uji Koefisien Determinasi $\left(\mathbf{R}^{2}\right)$.

\begin{tabular}{ccccc}
\hline Model & $\mathbf{R}$ & $\boldsymbol{R}$ Square & Adjusted $\boldsymbol{R}$ Square & $\begin{array}{c}\text { Std. Eror of The } \\
\text { Estimate }\end{array}$ \\
\hline 1 & 0,785 & 0,617 & 0,591 & 1.82416 \\
\hline
\end{tabular}

a. Predictors: (Constant), Aman, LB, BS, Kinf, Kkon.

Sumber: Data Primer diolah, 2016.

Dari hasil uji $\mathrm{R}$ dengan menggunakan SPSS for windows 16.0 menyatakan bahwa nilai $\mathrm{R}=0,785$ artinya $\mathrm{X} 1, \mathrm{X} 2, \mathrm{X} 3, \mathrm{X} 4$ dan $\mathrm{X} 5$ mempunyai hubungan yang kuat terhadap kesuksesan usaha pedagang handphone sepanjang jalan Moses. Sedangkan adjusted $R 2$ sebesar 0,591 artinya persentase sumbangan pengaruh variabel independen (X1, $\mathrm{X} 2, \mathrm{X} 3, \mathrm{X} 4$ dan X5) terhadap variabel dependen $(\mathrm{Y})$ sebesar 59,1\%, sedangkan sisa- nya sebesar $40,9 \%$ dijelaskan atau dipengaruhi oleh variabel lain yang tidak ada pada penelitian ini.

\section{Pengujian Hipotesis}

\section{Koefisien Regresi Individual (Uji-t)}

Hasil analisis Uji t dari output SPSS dapat disajikan sebagai berikut:

Tabel 8 . Hasil Analisis Uji t.

\begin{tabular}{|c|c|c|c|c|c|}
\hline \multirow[t]{2}{*}{ Model } & \multicolumn{2}{|c|}{$\begin{array}{c}\text { Unstandardized } \\
\text { Coefficients }\end{array}$} & \multirow{2}{*}{$\begin{array}{c}\text { Standardized } \\
\text { Coefficients }\end{array}$} & \multirow[t]{2}{*}{$\mathbf{t}$} & \multirow[t]{2}{*}{ Sig. } \\
\hline & B & Std. Error & & & \\
\hline (Constant) & -.222 & 2.162 & & -.103 & .918 \\
\hline B S & .368 & .118 & .275 & 3.117 & .003 \\
\hline K Inf & .294 & .134 & .196 & 2.198 & .031 \\
\hline${ }^{1}$ L B & .399 & .144 & .243 & 2.769 & .007 \\
\hline K Kon & .311 & .142 & .207 & 2.196 & .031 \\
\hline Aman & .394 & .166 & .183 & 2.372 & .020 \\
\hline
\end{tabular}

a. Dependent Variable: KU.

Sumber: Data primer diolah, 2016.

Dari hasil uji t dari output SPSS di atas, diperoleh bahwa keseluruhan variabel independen yaitu biaya sewa $\left(\mathrm{X}_{1}\right)$, kedekatan infrastruktur $\left(\mathrm{X}_{2}\right)$, lingkungan bisnis $\left(\mathrm{X}_{3}\right)$, kedekatan konsumen $\left(\mathrm{X}_{4}\right)$, dan keamanan memiliki nilai signifikansi lebih kecil dari nilai alpha $(0,05)$ sehingga hipotesa $\mathrm{H} 1, \mathrm{H} 2$, $\mathrm{H} 3, \mathrm{H} 4, \mathrm{H} 5$ diterima.

\section{Uji F}

Hasil analisis Uji F dari output SPSS 
dapat disajikan sebagai berikut:

Tabel 9. Hasil Uji F.

\begin{tabular}{llccccc}
\hline \multicolumn{1}{l}{ Model } & Sum of Squares & Df & Mean Square & F & Sig. \\
\hline 1 & Regression & 401.496 & 5 & 80.299 & 24.132 & $.000^{\mathrm{a}}$ \\
& & & & & \\
Residual & 249.566 & 75 & 3.328 & & \\
\cline { 2 - 4 } & & & & & \\
& Total & $\mathbf{6 5 1 . 0 6 2}$ & $\mathbf{8 0}$ & & & \\
\hline
\end{tabular}

a. Predictors: (Constant), Aman, LB, BS, Kinf, Kkon.

b. Dependent Variable: KU.

Sumber: Data primer diolah, 2016.

Dari hasil olah data diperoleh $\mathrm{F}_{\text {hitung }}=$ 24.132 dan nilai signifikansi sebesar 0,000 lebih kecil dari $\propto=0,05$, maka model regresi dapat dipakai untuk memprediksi kesuksesan usaha (Y), atau dapat dikatakan bahwa variabel X1, X2, X3, X4 dan X5 secara simultan berpengaruh terhadap $\mathrm{Y}$.

\section{Pembahasan}

Hasil analisis data menunjukkan bahwa semua variabel bebas X (biaya sewa, kedekatan infrastruktur, lingkungan bisnis, kedekatan konsumen, dan keamanan) secara parsial dan simultan berpengaruh positif dan signifikan terhadap kesuksesan usaha pedagang handphone sepanjang jalan Moses. Hal tersebut dapat dilihat dari penjelasan secara rinci sebagai berikut:

1. Hasil analisis data menunjukkan bahwa variabel biaya sewa memiliki pengaruh positif dan signifikan terhadap kesuksesan usaha. Hal ini dibuktikan dengan hasil statistik uji t untuk variabel biaya sewa diperoleh nilai $\mathrm{t}=3,117$ dengan tingkat signifikansi $0,003<0,05$, sehingga penelitian ini membuktikan hipotesis 1 yang menyatakan bahwa biaya sewa (X1) berpengaruh positif terhadap kesuksesan usaha. Hal ini memberikan bukti empiris bahwa biaya sewa lokasi mempengaruhi kesuksesan usaha penjualan handphone di sepanjang jalan Moses. Tinggi rendahnya biaya sewa mencerminkan posisi lo- kasi usaha strategis atau tidak. Lokasi yang strategis dalam teori wirausaha ditafsirkan sebagai lokasi dimana ada banyak calon pembeli, dalam artian lokasi ini mudah dijangkau, gampang dilihat konsumen, dan lokasi yang banyak dilalui atau dihuni target konsumen yang berpotensi membeli produk atau jasa yang dijual. Lokasi seperti ini cocok untuk usaha perdagangan barang atau jasa yang harus berhubungan langsung dengan pelanggan (Arsip Bisnis 2008, online).

2. Hasil analisis data menunjukkan bahwa variabel kedekatan infrastruktur memiliki pengaruh positif dan signifikan terhadap kesuksesan usaha. Hal ini dibuktikan dengan hasil statistik uji t untuk variabel kedekatan infrastruktur diperoleh nilai $\mathrm{t}=$ 2,198 dengan tingkat signifikansi $0,031<$ 0,05 , sehingga penelitian ini membuktikan hipotesis 2 yang menyatakan bahwa kedekatan infrastruktur (X2) berpengaruh positif terhadap kesuksesan usaha. Hal ini memberikan bukti empiris bahwa adanya saluran listrik yang memadai, saluran air yang lancar, akses jalan bagus dan terletak di tengah kota akan mendukung kesuksesan usaha penjualan handphone di sepanjang jalan Moses. Hal ini juga sejalan dengan pendapat Haming (2011) bahwa, dalam pemilihan lokasi usaha, faktor kedekatan infrastruktur sangat penting bagi kelancaran usahanya. 
3. Hasil analisis data menunjukkan bahwa variabel lingkungan bisnis memiliki pengaruh positif dan signifikan terhadap kesuksesan usaha. Hal ini dibuktikan dengan hasil statistik uji $\mathrm{t}$ untuk variabel lingkungan bisnis diperoleh nilai $\mathrm{t}=$ 2,769 dengan tingkat signifikansi $0,007<$ 0,05 , sehingga penelitian ini membuktikan hipotesis 3 yang menyatakan bahwa lingkungan bisnis (X3) berpengaruh positif terhadap kesuksesan usaha. Hasil penelitian ini sesuai dengan hasil penelitian terdahulu dari Indarti (2004). Hal ini memberikan bukti empiris bahwa adanya bisnis lain, banyak pesaing dan dekat dengan supplier mendukung kesuksesan usaha penjualan handphone di sepanjang jalan Moses.

4. Hasil analisis data menunjukkan bahwa variabel kedekatan konsumen memiliki pengaruh positif dan signifikan terhadap kesuksesan usaha. Hal ini dibuktikan dengan hasil statistik uji t untuk variabel kedekatan konsumen diperoleh nilai $\mathrm{t}=$ 2,196 dengan tingkat signifikansi 0,031 < 0,05 , sehingga penelitian ini membuktikan hipotesis 4 yang menyatakan bahwa kedekatan konsumen (X4) berpengaruh positif terhadap kesuksesan usaha. Hasil penelitian ini sesuai dengan penelitian yang dilakukan oleh Nurita (2013), dimana kedekatan konsumen berpengaruh positif terhadap kesuksesan usaha. Hal ini memberikan bukti empiris bahwa letak jalan Moses yang di tengah pemukiman, dikelilingi oleh lalu lintas yang padat dan dipadati oleh pejalan kaki mendukung kesuksesan usaha penjualan handphone di sepanjang jalan Moses.

5. Hasil analisis data menunjukkan bahwa variabel keamanan memiliki pengaruh positif dan signifikan terhadap kesuksesan usaha. Hal ini dibuktikan dengan hasil statistik uji t untuk variabel keamanan diperoleh nilai $\mathrm{t}=2,372$ dengan tingkat signifikansi $0,02<0,05$, sehingga penelitian ini membuktikan hipotesis 5 yang menyatakan bahwa keamanan (X5) berpengaruh positif terhadap kesuksesan usaha. Hal ini memberikan bukti empiris bahwa kawa- san jalan Moses yang berada di keramaian, bangunan kios kuat dan adanya tukang parkir guna menjaga kendaraan konsumen sehingga dapat memberikan rasa aman pada konsumen. Rasa aman ini mempengaruhi kesuksesan usaha penjualan handphone (Bisnis UKM, 2010, online).

\section{Simpulan}

Berdasarkan analisis data dan pembahasannya, maka diperoleh kesimpulan sebagai berikut:

1. Variabel biaya sewa (X1) berpengaruh positif dan signifikan terhadap kesuksesan usaha para pedagang handphone di sepanjang jalan Moses, Yogyakarta dengan koefisien regresi sebesar 0,368 , $\mathrm{t}_{\text {hitung }}$ sebesar 3,117 dan nilai Sig. sebesar 0,003 < 0,05 , maka hipotesis satu (H1) dapat diterima.

2. Variabel kedekatan infrastruktur (X2) berpengaruh positif dan signifikan terhadap kesuksesan usaha para pedagang handphone di sepanjang jalan Moses, Yogyakarta dengan koefisien regresi sebesar $0,294, t_{\text {hitung }}$ sebesar 2,198 dan nilai Sig. sebesar 0,031<0,05, maka hipotesis dua $(\mathrm{H} 2)$ dapat diterima.

3. Variabel lingkungan bisnis (X3) berpengaruh positif dan signifikan terhadap kesuksesan usaha para pedagang handphone di sepanjang jalan Moses, Yogyakarta dengan koefisien regresi sebesar 0,399, $t_{\text {hitung }}$ sebesar 2,769 dan nilai Sig. sebesar $0,007<0,05$, maka hipotesis tiga $(\mathrm{H} 3)$ dapat diterima.

4. Variabel kedekatan dengan konsumen (X4) berpengaruh positif dan signifikan terhadap kesuksesan usaha para pedagang handphone di sepanjang jalan Moses, Yogyakarta dengan koefisien regresi sebesar $0,311, t_{\text {hitung }}$ sebesar 2,196 dan nilai Sig. sebesar 0,031<0,05, maka hipotesis empat (H4) dapat diterima.

5. Variabel keamanan (X5) berpengaruh positif dan signifikan terhadap kesuksesan usaha para pedagang handphone di sepanjang jalan Moses, Yogyakarta dengan 
koefisien regresi sebesar 0,394 , $t_{\text {hitung }}$ sebesar 2,372 dan nilai Sig. sebesar 0,020 < 0,05 , maka hipotesis lima (H5) dapat diterima.

6. Variabel biaya sewa (X1), kedekatan infrastruktur (X2), lingkungan bisnis (X3), kedekatan konsumen (X4), dan keamanan (X5) secara simultan berpengaruh positif dan signifikan terhadap kesuksesan usaha para pedagang handphone di sepanjang jalan Moses, Yogyakarta, dengan nilai Fhitung $=24,132$ dan nilai Sig. 0 .

7. Nilai adjusted $R$ square diperoleh sebesar $0,591 \mathrm{Hal}$ ini berarti persentase sumbangan pengaruh variabel independen yaitu biaya sewa (X1), kedekatan infrastruktur (X2), lingkungan bisnis (X3), kedekatan konsumen (X4) dan keamanan (X5) terhadap variabel dependen yaitu kesuksesan usaha (Y) adalah sebesar 59,1\%, sedangkan sisanya sebesar 40,9\% dijelaskan atau dipengaruhi oleh variabel lain yang tidak ada pada penelitian ini.

\section{Implikasi}

Berdasarkan analisis data secara parsial (uji t) maupun simultan (uji F) dari variabel penelitian menunjukkan pengaruh signifikan terhadap kesuksesan usaha pedagang handphone sepanjang jalan Moses. Implikasi dari hasil penelitian ini adalah pemilihan lokasi usaha yang bagus dan strategis harus benarbenar diperhatikan agar berdampak positif terhadap kesuksesan usaha. Dalam penelitian ini faktor-faktor yang dipertimbangkan yaitu biaya sewa, kedekatan infrastruktur, lingkungan bisnis, kedekatan konsumen dan faktor keamanan.

\section{Saran}

Dengan mempertimbangan realita ketatnya kompetisi dalam perdagangan retail handphone, maka pengusaha harus benarbenar menjaga strategi pengelolaan usaha yang profesional dengan memperhatikan besarnya biaya sewa, memelihara infrastruktur, menjaga persaingan bisnis secara sehat, me- manfaatkan faktor kepadatan konsumen dengan kualitas pelayanan yang bagus serta tetap menjaga keamanan sehingga konsumen tetap tertarik untuk berbelanja handphone di kawasan jalan Moses.

\section{Daftar Pustaka}

Aro. 2008. Strategi Retailer Handphone di Yogyakarta. Online, (http://aropapyrus. blogspot.co.id/2008/12/strategiretailerha ndphonedi.htm), diakses 28 Januari 2016.

Arsip Bisnis, 6 September 2008. Lokasi Usaha. Online. (https://arsipbisnis.Word press.com/2008/09/06/lokasi-usaha/), diunduh 14 Februari 2016.

Basri. 2005. Pengantar Bisnis. Edisi Pertama. Yogyakarta: BPFE.

Bisnis UKM, 29 September 2010. Strategi Memilih Lokasi. Online. (http://bisnisuk m.com/strategimemilihlokasiusaha.html), diunduh 5 Maret 2016.

Duwi Consultan, 2011. Analisis Regresi Linier Berganda. Online, (http://duwicon sultant.blogspot.co.id/2011/11/analisis-re gresi-linier-berganda.html), diakses 28 Januari 2016.

Darmawan. 2013. Metode Penelitian Kuantitatif. Bandung: Remaja Rosdakarya.

Fakhturozi, Muhammad. 2012. "Infrastruktur, Permasalahan dan Solusinya". Online, (http://hati.unit.itb.ac.id/2012/03/16/ infrastruktur-permasalahandansolusinya), diunduh 8 Oktober 2015.

Haming, M. dan Mahfud N. (2011). Manajemen Produksi Modern, Edisi Kedua. Jakarta: Bumi Aksara.

Heizer, J. dan Barry, R. (2009). Operations Management-Manajemen Operasi. Edisi 9 Buku 1. Jakarta: Salemba Empat.

Grigg, Neil, 1988. Infrastructure 
Engineering and Management. John Wiley and Sons.

Indarti, Nurul. 2004. "Business Location and Success: The Case of Internet Café Business in Indonesia". Gadjah Mada International Journal of Business, vol. 6, No. 2: pp. 171-192.

Irianto, Agus. 2007. Statistika Konsep Dasar dan Aplikasinya. Jakarta: Kencana.

Kamus Umum Bahasa Indonesia. Online, (http://kbbi.web.id/), diakses 5 November 2015.

Kodoatie, Robert J. (2005). Pengantar Manajemen Infrastruktur. Yogyakarta: Pustaka Pelajar.

Nurita, Ifrina. 2013. "Identifikasi Pengaruh Lokasi Usaha terhadap Tingkat Keberhasilan Usaha Minimarket Waralaba di Kabupaten Jember dengan Sistem Informasi Geografis". Online, (http://repository.une j.ac.id/bitstream/handle/123456789/45/ar tikelifrina.pdf?sequence $=3$ ), diakses 28 Januari 2016.

Puskakom. 2015. Jumlah Pengguna Internet Indonesia. Online, (http://tekno.liputan6. com/read/2197413/jumlah-penggunainter net-indonesia-capai-881-juta), diakses 28 Januari.

SPSS Indonesia. Online, (http://www.spss in donesia.com/2014/02/cara-mudahmelaku kan-uji-t-dengan-spss.html\#).

Sugiyono, 2013. Metode Penelitian Manajemen. Bandung: Alfabeta.

Suharta. "Makalah Faktor Keberhasilan Usaha". Online, (http://staff.uny.ac.id/sites /default/files/tmp/makalah\%20faktor\%20 keberhasilan\%20usaha.pdf), diakses 28 Januari 2016.

Tarigan, Robinson. 2006. Perencanaan Pembangunan Wilayah. Jakarta: Bumi Aksara.

Tjiptono, Fandy. 2012. Pemasaran Jasa. Jatim: Bayumedia.

Wibowo, 2014. (http://www.wibowopajak. com/2014/03/pengertiandefinisi-biaya-se wa-rent.html).

Zimmerer, Thomas W. et. al. (2008). Kewirausahaan dan Manajemen Usaha Kecil (Buku 1). Jakarta: Salemba Empat. 